\title{
TECNOLOGIA E LEITURA
}

Wepner, S. B.; Valmont, W. J. \& Thurlow, R. (orgs.).2000. Linking literacy and technology. Newark: IRA, xiv + 252 páginas.

Composto pelo esforço de vários pesquisadores e docentes, de várias universidades norteamericanas, o livro resenhado apresenta tema que vem chamando a atenção especialmente de meados dos anos oitenta para cá, com um crescimento apreciável na última década. Trata da inserção das novas tecnologias no ensino no caso específico da alfabetização/leitura. Muito do enfocado ainda está infelizmente muito distante da realidade brasileira, especialmente da escola pública. Todavia, para haver progresso é necessário que autoridades educacionais e docentes se preocupem com estas incorporações rapidamente. Há inovações tecnológicas já encontradas em algumas escolas brasileiras. Outras ainda requerem baixo custo para sua implantação, podendo ser viabilizadas com competência, cri atividade e boa vontade de docentes e administradores de escola. Isto sem falar da possibilidade de buscar suporte na comunidade integrando melhor escola e sociedade.

O pré-texto do livro compreende palavras iniciais de Leu Jr. lembrando a importância das novas tecnologias especialmente decorrentes do uso do computador. Esta também é a mensagem do Prefácio. Seguem os agradecimentos e a apresentação dos autores. O corpo do livro foi estruturado em três sessões com números desiguais de capítulos. O pós-texto é constituído por um Apêndice com endereços de companhias que produzem softwares de interesse para a área; índice de autores e índice de conteúdo, bastante úteis aos leitores.

A primeira parte do livro oferece um suporte teórico sobre o problema enfocado no livro. O primeiro capítulo é assinado por Valmon e Wepner e trata da tecnologia como suporte para a aprendizagem. O texto é bastante convincente quanto à importância de modernizar a sala de aula, usando novas tecnologias, até mesmo para se aproximar da vivência da criança de hoje fora da escola com o rádio, os vídeo-discos digitais, os videocassetes, os jogos eletrônicos, a televisão, o computador doméstico, a Internet e outras tecnologias. Elas precisam integrar o ambiente acadêmico no ensino fundamental e médio, dizem os autores. De fato, devem estar incluídas em todos os níveis de ensino.

O último capítulo desta parte leva a assinatura de Thurlow e trata de como começar a usar tecnologia em sala de aula. Mesmo para os que estão pouco empenhados no assunto, há apoio suficiente para a leitura deste capítulo.

A segunda parte entra no ciber-espaço e é um convite a que cada docente encontre seu próprio meio de usar as tecnologias. É constituída por quatro capítulos, dos quais o primeiro é da autoria de Fox e Mitchell e trata do uso de tecnologia para atividades envolvendo vocabulário (ensinoaprendizagem, desenvolvimento). Apresenta instrumentos para avaliação da adequação de softwares sobre as propriedades de vários deles úteis à aprendizagem do léxico inglês, informação muito útil para quem leciona a referida língua.

O capítulo seguinte trata do uso da tecnologia para o desenvolvimento da leitura e foi escrito por Wepner e Ray. Após uma breve justificativa para o uso das novas tecnologias, os autores apresentam algumas tecnologias eletrônicas como os livros eletrônicos (CDROMs; jogos interativos para leitura). Apresentam roteiros de checagem a serem utilizados para avaliar o material, especialmente suas características educacionais. Preliminarmente é necessário que o software 
ofereça algo que o professor não possa oferecer recorrendo às formas tradicionais de ensino; deve realmente viabilizar atingir os objetivos propostos; conceitos e conteúdos devem ser precisos, apropriados, e não discriminatórios quanto a raça, idade, gênero, etnia e a portadores de deficiências. É preciso lembrar que se está buscando formar leitores independentes.

O Capítulo 5 foi elaborado por Sullivan e Sharp e trata da relação tecnologia-desenvolvimento da escrita. Segue estrutura do anterior, justificando o uso da tecnologia no ensino da escrita. Enfocam aspectos ainda carentes de pesquisa, tais como processamento de palavra, criatividade e produtividade entre outros. Oferecem diretrizes de apoio e indicações úteis aos docentes.

O último capítulo desta parte é de Roe e trata do uso de tecnologia nas várias áreas de conteúdo que requerem leitura e escrita. São apresentadas rapidamente várias ferramentas tecnológicas: transparências, gravações sonoras, video-disco digital e uso do computador/base de dados, apresentação de software, Internet. Cita exemplo de tecnologia no ensino de matemática, ciências, estudos sociais e artes. Apresenta um questionário para avaliação dos Web Sites.

A última parte do livro é constituída por dois capítulos que esperam estimular o casamento do ensino com a tecnologia no ciber-espaço. O primeiro deles foi redigido por Valmont e enfoca a atuação do professor quando a sala de aula já está rica em tecnologia. É um olhar no comportamento de alunos e professores em situações em que a tecnologia já foi incorporada à rotina de sala de aula. A ênfase recai na aprendizagem assistida pela tecnologia. Valmont refere-se aos papéis do professor neste ambiente de ensino, destacando por exemplo a importância da orientação aos alunos para a seleção de material para que não se percam em milhões de páginas e que muitas vezes podem ser lixo. Uma tarefa é orientar o aluno antes que vá ao computador, por exemplo, definir claramente o que irá procurar; que palavras-chave usará na busca; como usar os vários endereços e símbolos etc. Lembra que também o papel do aluno mudou com as novas tecnologias, tem outras responsabilidades como cuidado e preservação dos materiais (são caros), uso ético dos meios etc. Arrola os 17 itens mínimos, além dos tradicionais que precisam estar presentes em uma sala de aula para que se possa chamá-la de sala tecnologicamente enriquecida. Entre estes itens estão: linha telefônica direta na classe; acesso à Internet por vários computadores; no mínimo seis estações de trabalho em multimídia; conversa digital; scanner para textos e figura; impressão a cores e recursos de programação; um projetor LCD (liquid crystal display); um leitor de livro (ebook), uma torre de CD; televisão e videocassete; computadores portáteis para os alunos trabalharem fora da sala, inclusive em casa; computadores portáteis para os professores; dinheiro para participar de salas de discussão online; WebWhacker 2000 ou similar; CD-ROM de dicionários, enciclopédias e outros materiais com condições para cópia; inscrição no Classroom Connect; acervo aos recursos à distância pelos alunos e professores. Enfoca ainda aspectos da organização e arranjo da classe, programação etc., oferecendo exemplos muito úteis.

O último capítulo é um balanço que Balajthy propõe ao professor quanto à compensação que terá no esforço para usar a tecnologia. Aponta o que os alunos podem ganhar (e o professor também) em atualização e contato com outras pessoas. Certamente, o comportamento e as atitudes precisam mudar. Entre estas mudanças está a formação de infodetetives, isto é, alunos que dominem as estratégias de gerar e selecionar as perguntas corretas; saibam desenvolver perguntas; buscar as respostas; organizar e apresentar as informações.

Infelizmente, na realidade brasileira, mesmo as escolas melhores equipadas com recursos tecnológicos estão muito longe da realidade apresentada no livro. Entretanto, algumas mudanças 
comportamentais e na formação dos professores precisam ir sendo estabelecidas até para assegurar que, com criatividade e empenho, mesmo que sem tantos recursos consiga mudar a realidade da sala de aula incluindo paulatinamente novas tecnologias eletrônicas ou não. É preciso caminhar em busca da inovação.

\section{Geraldina Porto Witter}

UMC / PUC-Campinas 